\title{
Commentary: Molecular pathogenesis of aortic stenosis: Will the puzzle pieces ever fit together?
}

Emily Shih, MD, ${ }^{\mathrm{a}}$ John J. Squiers, MD, ${ }^{\mathrm{a}}$ Ronald D. Baxter, MD, ${ }^{\mathrm{a}, \mathrm{b}}$ and J. Michael DiMaio, MD ${ }^{\mathrm{b}, \mathrm{c}}$

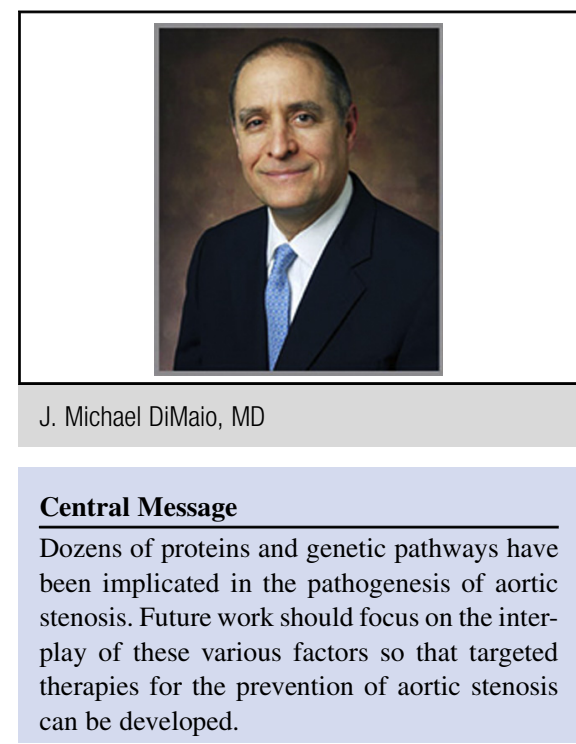

See Article page e1.
Aortic stenosis (AS) is the most common valvular heart disease in developed countries, ${ }^{1}$ affecting up to $10 \%$ of the population in the eighth decade of life ${ }^{2}$ and generally associated with poor survival in moderate or severe stages. ${ }^{3}$ The pathology of AS is described as a progressive fibro-calcific remodeling resulting in thickened valve leaflets eventually leading to obstruction of cardiac outflow. ${ }^{4}$ This remodeling is a result of genetic predispositions causing complex structural anomalies such as bicuspid valve, metabolic syndromes with lipoprotein deposition and oxidation, chronic inflammation, and osteoblastic transition of interstitial cells in valvular tissue with active calcification of valve leaflets. ${ }^{4}$ The biological process underlying the development of AS remains an area of intensive investigation-a cursory search of the literature revealed more than 20 papers examining potential genetic pathways impacting AS published within the last 5 years alone (Table 1). ${ }^{5-25}$ Nevertheless, there are currently no available preventative therapies for AS!

In this article, Khan and colleagues ${ }^{26}$ present work which delineates the role of urotensin II, urotensin-related peptide, and the urotensin receptor in the pathophysiology of calcified AS. Vasoactive mediators in this family play a role in cardiovascular diseases such as atherosclerosis and heart failure. ${ }^{27-29}$ Tissue samples from 36 calcified and 25 normal aortic valves were harvested and used to isolate human aortic valve interstitial cells. Further testing revealed elevated mRNA expression of urotensin II, urotensin-related peptide, and urotensin receptor (urotensin receptor family) in calcified valves compared with normal valvular tissue through real-time polymerase chain reaction. These findings demonstrate upregulation of genetic pathways related to increased mineralization and cell proliferation after treatment of human aortic valve interstitial cells with the urotensin receptor family. Thus, the potential impact of the urotensin receptor family on the pathophysiology of AS was demonstrated.
TABLE 1. Summary of factors, proteins, and pathways implicated in the promotion or prevention of calcified aortic stenosis from publications between 2015 and 2019

\begin{tabular}{|c|c|}
\hline Promotes & Prevents \\
\hline Interleukin-33 & Nobiletin (NBT) \\
\hline $\begin{array}{l}\text { Notch1-Runt-related transcription factor } 2 \\
\quad \text { (RUNX2) }\end{array}$ & Gla-rich protein (GRP) \\
\hline $\begin{array}{l}\text { Ne-carboxymethyl-lysine (CML)/receptor } \\
\text { for advanced glycation end products } \\
\text { (RAGE) }\end{array}$ & Apelin \\
\hline $\begin{array}{l}\text { C-C motif chemokine receptors (CCRs) } \\
\text { CCL2/CCR2 }\end{array}$ & \\
\hline Sphingosine 1-phosphate receptors & \\
\hline Toll-like receptor 4 signaling & \\
\hline $\begin{array}{l}\text { Ectonucleotide pyrophosphatase/ } \\
\text { phosphodiesterase } 1 \text { (NPP1) }\end{array}$ & \\
\hline Lipoprotein(a) & \\
\hline Wnt5a, Wnt5b, Wnt 11 & \\
\hline Cadherin-11 & \\
\hline SOX9 & \\
\hline $\begin{array}{l}\text { Bone morphogenetic protein-2 (BMP-2) and } \\
\text { Transforming growth factor beta } 1 \text { (TGF- } \\
\beta 1 \text { ) }\end{array}$ & \\
\hline
\end{tabular}

(Continued) 
TABLE 1. Continued

\begin{tabular}{l}
\hline \multicolumn{1}{c}{ Promotes } \\
\hline Histone acetyltransferase (HAT) \\
Matrix metalloproteinases (MMPs) \\
\hline Leptin \\
Interleukin-32 \\
Galectin-3 \\
$\begin{array}{l}\text { Oxidative transformation of low-density } \\
\text { lipoprotein (OxLDL) }\end{array}$ \\
High-mobility group box-1 protein \\
(HMGB1) \\
\hline
\end{tabular}

The rise of transcatheter valve therapies has revolutionized the treatment of AS over the last decade. We anticipate the next sea-change in the management of aortic valve disease will focus on the prevention of AS, rather than treatment at its end stage. The work of Khan and colleagues has added another puzzle piece to a growing pile of genetic pathways implicated in the pathogenesis of AS. Future work should focus on delineating the interplay between these many pathways-putting the puzzle pieces together-so that targeted therapies can be developed for the prevention of AS.

\section{References}

1. Osnabrugge RLJ, Mylotte D, Head SJ, Van Mieghem NM, Nkomo VT, LeReun CM, et al. Aortic stenosis in the elderly: disease prevalence and number of candidates for transcatheter aortic valve replacement: a meta-analysis and modeling study. J Am Coll Cardiol. 2013;62:1002-12.

2. Joseph J, Naqvi SY, Giri J, Goldberg S. Aortic stenosis: pathophysiology, diagnosis, and therapy. Am J Med. 2017;130:253-63.

3. Strange G, Stewart S, Celermajer D, Prior D, Scalia GM, Marwick T, et al. Poor long-term survival in patients with moderate aortic stenosis. J Am Coll Cardiol. 2019;74:1851-63.

4. Squiers JJ, Harrington KB, Arsalan M, DiMaio JM. Preventative medicine: the next revolution in the treatment of aortic stenosis. J Thorac Cardiovasc Surg. 2016;151:263-4.

5. He Y, Guo J, Wang C, Zhu D, Lu LM. IL-33 promotes the progression of nonrheumatic aortic valve stenosis via inducing differential phenotypic transition in valvular interstitial cells. J Cardiol. August 12, 2019 [Epub ahead of print].

6. Toshima T, Watanabe T, Narumi T, Otaki Y, Shishido T, Aono T, et al. Therapeutic inhibition of microRNA-34a ameliorates aortic valve calcification via modulation of Notch1-Runx2 signaling. Cardiovasc Res. August 18, 2019 [Epub ahead of print].

7. Wang Z, Li L, Du R, Yan J, Liu N, Yuan W, et al. CML/RAGE signal induces calcification cascade in diabetes. Diabetol Metab Syndr. 2016;8:83.

8. Xu K, Huang Y, Zhou T, Wang C, Chi Q, Shi J, et al. Nobiletin exhibits potent inhibition on tumor necrosis factor alpha-induced calcification of human aortic valve interstitial cells via targeting ABCG2 and AKR1B1. Phytother Res. 2019;33:1717-25.

9. Zhu E, Liu Z, He W, Deng B, Shu X, He Z, et al. CC chemokine receptor 2 functions in osteoblastic transformation of valvular interstitial cells. Life Sci. 2019; 228:72-84.
10. Fernández-Pisonero I, López J, Onecha E, Dueñas AI, Maeso P, Crespo MS, et al. Synergy between sphingosine 1-phosphate and lipopolysaccharide signaling promotes an inflammatory, angiogenic and osteogenic response in human aortic valve interstitial cells. PLoS One. 2014;9:e109081.

11. Mahmut A, Boulanger M, Bouchareb R, Hadji F, Mathieu P. Adenosine derived from ecto-nucleotidases in calcific aortic valve disease promotes mineralization through A2a adenosine receptor. Cardiovasc Res. 2015;106: 109-20.

12. Lee A, Wei S, Schwertani A. A Notch more: molecular players in bicuspid aortic valve disease. J Mol Cell Cardiol. 2019;134:62-8.

13. Viegas C, Rafael M, Enriquez J, Teixeira A, Vitorino R, Luís IM, et al. Gla-rich protein acts as a calcification inhibitor in the human cardiovascular system. Arterioscler Thromb Vasc Biol. 2015;35:399-408.

14. Yuan ZS, Zhou YZ, Liao XB, Luo JW, Shen KJ, Hu YR, et al. Apelin attenuates the osteoblastic differentiation of aortic valve interstitial cells via the ERK and PI3-K/Akt pathways. Amino Acids. 2015;47:2475-82.

15. Sung DC, Bowen CJ, Vaidya KA, Zhou J, Chapurin N, Recknagel A, et al. Cadherin-11 overexpression induces extracellular matrix remodeling and calcification in mature aortic valves. Arterioscler Thromb Vasc Biol. 2016;36: 1627-37.

16. Huk DJ, Austin BF, Horne TE, Hinton RB, Ray WC, Heistad DD, et al. Valve endothelial cell-derived TGF $\beta 1$ signaling promotes nuclear localization of Sox9 in interstitial cells associated with attenuated calcification. Arterioscler Thromb Vasc Biol. 2016;36:328-38.

17. Song R, Fullerton D, Ao L, Zheng D, Zhao KS, Meng X. BMP-2 and TGF- $\beta 1$ mediate biglycan-induced pro-osteogenic reprogramming in aortic valve interstitial cells. J Mol Med (Berl). 2015;93:403-12.

18. Li S, Kao Y, Chung C, Chen WY, Cheng WL, Chen YJ. Activated p300 acetyltransferase activity modulates aortic valvular calcification with osteogenic transdifferentiation and downregulation of Klotho. Int J Cardiol. 2017;232: 271-9.

19. Perrotta I, Sciangula A, Aquila S, Mazzulla S. Matrix metalloproteinase-9 expression in calcified human aortic valves: a histopathologic, immunohistochemical, and ultrastructural study. Appl Immunohistochem Mol Morphol. 2016;24:128-37.

20. Rosa M, Paris C, Sottejeau Y, Corseaux D, Robin E, Tagzirt M, et al. Leptin induces osteoblast differentiation of human valvular interstitial cells via the Akt and ERK pathways. Acta Diabetol. 2017;54:551-60.

21. Tsai C, Chiu Y, Lee Y, Hsieh CT, Shieh DC, Tsay GJ, et al. Interleukin-32 plays an essential role in human calcified aortic valve cells. Eur Cytokine Netw. 2018; 29:36-47.

22. Albanese I, Yu B, Al-Kindi H, Barratt B, Ott L, Al-Refai M, et al. Role of noncanonical Wnt signaling pathway in human aortic valve calcification. Arterioscler Thromb Vasc Biol. 2017;37:543-52.

23. Sádaba JR, Martínez-Martínez E, Arrieta V, Álvarez V, Fernández-Celis A, Ibarrola J, et al. Role for galectin-3 in calcific aortic valve stenosis. J Am Heart Assoc. 2016;5.

24. Nsaibia M, Boulanger M, Bouchareb R, Mkannez G, Le Quang K, Hadji F, et al. OxLDL-derived lysophosphatidic acid promotes the progression of aortic valve stenosis through a LPAR1-RhoA-NF- $\mathrm{BB}$ pathway. Cardiovasc Res. 2017;113: 1351-63.

25. Wang B, Li F, Zhang C, Wei G, Liao P, Dong N. High mobility group box-1 protein induces the osteogenic phenotype changes aortic valve interstitial cells. $J$ Thorac Cardiovasc Surg. 2016;151:255-62.

26. Khan K, Albanese I, Yu B, Shalal Y, Al-Kindi H, Alaws H, et al. Urotensin II, urotensin-related peptide and their receptor in aortic valve stenosis. J Thorac Cardiovasc Surg. 2021;161:e1-15.

27. Ames RS, Sarau HM, Chambers JK, Willette RN, Aiyar NV, Romanic AM, et al. Human urotensin-II is a potent vasoconstrictor and agonist for the orphan receptor GPR14. Nature. 1999;401:282-6.

28. Bousette N, Patel L, Douglas SA, Ohlstein EH, Giaid A. Increased expression of urotensin II and its cognate receptor GPR14 in atherosclerotic lesions of the human aorta. Atherosclerosis. 2004;176:117-23.

29. Douglas SA, Tayara L, Ohlstein EH, Halawa N, Giaid A. Congestive heart failure and expression of myocardial urotensin II. Lancet. 2002;359: 1990-7. 